\title{
Validation of SERVQUAL Model in Relation to Customer Loyalty: Evidence from FMCGs in Pakistan
}

\author{
Ammar Ahmed ${ }^{1 *}$, Faiz Muhammad Khuwaja ${ }^{2}$, Ismail Bin Lebai Othman ${ }^{1}$, \\ Muhammad Asif Qureshi ${ }^{1}$, Rao Akmal Ali ${ }^{1}$
}

\begin{abstract}
The aim of this study is to make a scientific contribution to understanding the relationship between SERVQUAL model and customer loyalty. The primary objective is to examine the composite relationship between SERVQUAL model and customer loyalty from the perspective of FMCG customers. The second objective is to investigate the relationship between each dimension of the SERVQUAL model in relation to customer loyalty. Through the self-rated survey, data was collected from the 400 walkin customers of FMCG firms. Using PLS-SEM approach, the validation of SERVQUAL model was analyzed in relation to customer loyalty. Also, the influence of each dimension of service quality on customer loyalty was examined. The findings of primary objective revealed that the SERVQUAL model is significantly and positively linked to the customer loyalty. Further, the findings of the second objective revealed that each dimension of the SERVQUAL model has a significant relationship with the customer loyalty and depicts noteworthy contribution of service quality in literature. These findings suggest that SERVQUAL model is capable of being effectively used to evaluate the service quality in the FMCG market of Pakistan. Implications and future opportunities of the study are discussed.
\end{abstract}

Keywords: SERVQUAL, Service Quality, Customer Loyalty, Fast Moving Consumer Goods, PLS-SEM.

\section{Introduction}

This study aims to investigate the validation of SERVQUAL model and its relationship with the customer loyalty in the Fast Moving Consumer Goods (FMCG) market in Pakistan. The term FMCG refers to those products or goods which can be consumed wholly or in part over a short period of time like in a few days, weeks, months, and/or within a year of purchase (Moolla \& Bisschoff, 2012). The products under FMCGs have a very short shelf-life due to high consumer demand based on the quality of product or service and/or the rapid deterioration nature of the products (Moolla \& Bisschoff, 2012). Likewise, the core focus of the FMCG firms marketing activities is to develop, maintain, and enhance the customer's loyalty towards its marketed products or services (Ngobo, 2017). So, the increasing unpredictability, product differentiation, and high https://doi.org/10.30537/sijmb.v4i2.111

${ }^{1}$ College of Business, University Utara Malaysia, Sintok Malaysia

* Corresponding Author: ammar_malik419@yahoo.com

${ }^{2}$ Department of Business Administration, Sukkur IBA University 
competitive pressure have increased the importance of customer loyalty in the FMCG marketplace.

According to the Economist (2013), FMCG firms have a scope of growth in Pakistan market. This is also evident from the Pakistan Economic Survey (2017) which revealed a significant growth of 9.65 percent in the FMCG industry of Pakistan. There are numerous reasons for this, but importantly Pakistan's growing population and its major portion were emerging middle-class consumers (Economist, 2013). In Pakistan, various multinational and national FMCG firms are operating and heavily invested in its production and distribution. Even though there numerous FMCG firms are operating in Pakistan, there is a strong scope of growth in terms of market share which can be increased by understanding consumers and distributing the right products and brands through service quality (Economist, 2013). Further, Shazia Syed, a CEO of Unilever Pakistan Limited also stated that "most importantly, the local industry needs to step up cost efficiencies and quality standards in order to survive in this new competitive world". She further stated that "the FMCG sector is also confident of growth being fueled by rising consumer confidence" (News, 2017). Therefore, there is a need that FMCG firms should focus on its quality standards which can be maintained through the delivery of service quality.

In the recent past, the notion of service quality has been very lucrative for management executives and researchers on account of its powerful influence on organizational performance, cost reduction, consumer delight, consumer faithfulness and overall success of the business (Gupta, Si, \& Si, 2016; Gurău, 2003; Sureshchandar, Rajendran, \& Anantharaman, 2002). Chou, Lu, and Chang (2014) noticed an unbroken chain of research studies conducted refining the conception, modeling, assessment, research procedure, and the data assessment phenomenon regarding service quality, which has been leading the researchers for the establishment of a mature foundation in this pertinent area (Seth, Deshmukh, \& Vrat, 2005). In addition to that, the service quality has remained an attractive area for academicians as well as marketing managers because of the crucial role of service staff in the process of rendering services leading to customer retention and loyalty (F. Ali, Zhou, Hussain, Nair, \& Ragavan, 2016; M. Ali \& Raza, 2017).

The conceptualization of service quality can better be explained by considering the concepts of service and quality separately. The service quality is composed of two separate but mutually complimenting components, which is firstly the service and secondly the quality. The services tend to be the intangible behavioral beings rather than physical units and can be portrayed as the performances, conduct, actions, and procedures. Whereas the quality is deemed as a customer's judgment of the level to which the actual delivered product or service meets his or her anticipated belief (Singh, 2016). Precisely, the conception of service quality may be considered as the level of disparity between customers expected level of service performed prior to coming across

Sukkur IBA Journal of Management and Business - SIJMB | Volume 4 No. 2 July - December 2017 @) Sukkur IBA University 
that service, and their views of the actual service encountered (Asubonteng, McCleary, \& Swan, 1996; Zargar, 2016).

More recently, a product quality, process quality and the total quality management have become a primary concern in the FMCG and manufacturing region, and service is now recognized to be critical for all organizations (Ahmed, 2016; Lewis, 1993). The firms offering finer service are evidently found with growing market share, leading to soaring levels of profits via premium prices thus, the firms with better service quality are reported to realize an 8 percent increased price premium than their competitors (Buell, Campbell, \& Frei, 2016; Ofori, Boakye, \& Narteh, 2016). Besides, the extension of good word of mouth of the happy customers is an additional consequent benefit of superior service (A Parasuraman, Berry, \& Zeithaml, 2002). Subsequently, the service quality is acknowledged as a captivating competitive strategy, benefiting to both counterparts that are the service providers and their clients, generating interactive intentions of customers to further advocate the firm positively which ultimately leads to profit multiplication to the firm (Ahmed, 2016).

Different researches conducted at different times have been portraying the high correlation found between the customer satisfaction and their positive intentions for good word of mouth (M. J. Chang, Kang, Ko, \& Connaughton, 2017; Hartline \& Jones, 1996). Such sort of positive intentions on behalf of satisfied customers is indispensable for the firm's survival because these regarded as a symbol of customer loyalty (Akbar \& Parvez, 2009; Ammar Ahmed, 2016). Therefore, it is found that the ensuring service quality by the FMCG firms, in particular, would increase the customer orientation positively about the firm and take the firm towards generation of the positive word of mouth, greater perceived reliability of the firm's products leading to customer satisfaction with a resulting customer loyalty (Ahmed, 2016).

Moreover, service quality is recognized as a key feature for any organization to gain a competitive advantage via sustainable customer relationships (Wilson, Zeithaml, Bitner, \& Gremler, 2016). The quality of the services appears as the main cause to improve the bottom-line performance of any firm resulting in exceeding the perceived level of service desired by customers (Chumpitaz \& Paparoidamis, 2004). In order to measure the service quality, a group of prominent researchers V. A. Z. Parasuraman, Berry, and Zeithaml (1988) has operationalized it as a five-dimensional construct consisted of tangibility, reliability, assurance, responsiveness, and empathy.

This article is particularly concerned with the validation of a service quality construct 'SERVQUAL' with an explicit focus on the FMCG industry of Pakistan. Previously published studies regarding the applications and usefulness of SERVQUAL have been conducted in the developed countries like USA, Canada, North America, Australia, Hong Kong, India and Singapore, and in context of retail banking, telecom sector, hotel industry, transportation industry, healthcare, tourism industries (Gupta et al., 2016;

Sukkur IBA Journal of Management and Business - SIJMB | Volume 4 No. 2 July - December 2017 @) Sukkur IBA University 
Turel \& Serenko, 2006). Furthermore, a considerable amount of literature has been published on customer loyalty (Leahy (2009); Moolla and Bisschoff (2012)), however, a little attention has been paid towards the examination of SERVQUAL model and its relationship with the customer loyalty in the FMCG market in Pakistan. Therefore, this study aims to provide the empirical evidence by validating the SERQUAL model in the developing country FMCG market context and also its significant role in the development of customer loyalty which also bridges the literature gap. Put differently, there are two objectives of this study,

i) To investigate the relationship between SERVQUAL model and customer loyalty in the Pakistan FMCG market.

ii) To examine the relationship between each dimension of the SERVQUAL model and customer loyalty in the Pakistan FMCG market.

The following sections of the study provide the definition of service quality, review of literature, the method used in current study followed by outcomes and deductions on the basis of the findings of the present study discussed in the last section.

\section{Literature Review}

This section discussed the literature regarding the service quality, its dimensions, and measurement of the service quality. Thereafter, the relationship between service quality and customer loyalty has been explained. Based on the literature discussed, the hypotheses were established to empirically examine in the context of this study.

\subsection{Definitions of Service Quality}

In order to define and evaluate service quality, it is crucial to comprehend the concept of service, which is defined as, "the intangible offer by one company to another company or individual in exchange of money for the satisfaction of their need" (Kotler $\&$ Keller, 2009). The primary focus of all the definitions of service quality is how to better fulfill customers' needs and how to match the service delivered to customers' expectations (Lewis, 1993; Radojevic, Stanisic, \& Stanic, 2015). The notion of service quality is also defined as, "a comparison between consumer expectations of service and consumer perceptions of the service level provided" (Anantharanthan Parasuraman, Zeithaml, \& Berry, 1985).

In the literature for service quality, expectations are taken as wishes or wants, for example, anything customer expects from the service provider, rather than it would actually offer, and these expectations are formed on the basis of previous understanding of customers about the company and its value propositions, relative to its competitors and also based on word-of-mouth communications (Akbar \& Parvez, 2009; Lewis, 1993). 


\subsection{Service Quality}

The literature regarding the field of management and marketing considered service quality as "the difference between the expected and actual received services by the customers", as the best method to measure service quality perception that is helpful for the firm management to recognize and manage the service gaps (Ahmed, 2016). This gap between expected and actual quality has the direct influence on the satisfaction of the customer. The lesser is the gap between the actual and expected service, the greater is the customer satisfaction (Balaji, 2009). The phenomenon of "customer needs, culture, past experiences and the other's word of mouth" provide the basis for developing the customers' expectations in their mind. Thus, the satisfaction of the customer is the product of the perceived quality of any service which comes through the match of actual service rendered and the expected service (Gounaris, Tzempelikos, \& Chatzipanagiotou, 2007).

In a recent study by Sathiyabama and William (2015), the service quality of retailers was examined in Coimbatore city with a consequent evidence of a strong impact of "responsiveness, attractiveness, assurance and reliable service" on the retailer's service. Furthermore, a study of service quality in retail outlets by Singh (2016) discovered a significant connection between service quality and satisfaction of the customer. Similarly, this assertion was confirmed by Singh (2013) regarding the strong relationship between service quality and the customer loyalty in retail channels. Similarly, another study of retailer behavior conducted in India by Khare, Parveen, and Rai (2010) using the traditional SERVQUAL scale, revealed a high encouraging correlation between service quality dimensions.

Moreover, $\mathrm{Yu}, \mathrm{Wu}$, Chiao, and Tai (2005) found that a high-quality perception by customers can be directly correlated to the customer satisfaction as well as staff retention, by means of enhanced profitability, market share and an overall corporate reputation. After the high satisfaction level, the customers find themselves in good relationship with the organization and consider it to the high extent (Rootman, 2006). Similar findings were extended by Ofori et al. (2016), F. Ali et al. (2016), Akbar and Parvez (2009) and R. Oliver (1993), who also confirms that the service quality being assessed at the transaction level actually precedes the consumer satisfaction, whereas the customer satisfaction that signifies the quality of service, is the predecessor of relating the customer to the company. Hurley and Estelami (1998) argue that observation of service quality determines the customers' feelings regarding the company and which ultimately settle on their loyalty to and the relationship with the company in the long run.

The advocated advantages of the customer loyalty with company results in their less price sensitivity, greater interest and an enhanced recommendation of their favorite brands (Dowling \& Uncles, 1997). The premium quality services bring in the recurrence of sales among the customers along with an enhanced market share to the company

Sukkur IBA Journal of Management and Business - SIJMB | Volume 4 No. 2 July - December 2017 @) Sukkur IBA University 
(Tsoukatos \& Rand, 2006). Moreover, a similar expression is extended by Lee and Hwan (2005) who asserts that the satisfied customers have more favorable intentions for the company that motivates them for a repurchase behavior with an ultimate direct impact on the profit of the company.

The review of literature above concludes that the quality of service impacts the customer satisfaction and customer loyalty directly. In addition to that, V. A. Z. Parasuraman et al. (1988) had developed the SERVQUAL scale, but, A Parasuraman et al. (2002) had reassessed the same study with three types of service industries considering banking, insurance and telephone repair. In that study, the data were collected from five nationally known companies of USA consisting of one Telephone Company, two Insurance Companies and two Banks. Data randomly were collected from the customers of the above mentioned five companies around 1800 to 1900. This study enhanced the validity of the SERVQUAL scale; unfortunately, this and most of the other studies on SERVQUAL, have been carried out in the context of developed countries. The cultural differences in the developing countries are still a matter of concern. Therefore, the potential need to assess the validation of SERVQUAL scale in the developing economies still remains unfulfilled. To report this gap, the current study goes to re-validate the SERVQUAL model in the FMCG market in Pakistan. For that purpose, the current study considered the customer loyalty as a criterion construct to accurately measure the validation of the SERVQUAL scale.

\subsection{Service Quality Dimensions}

The well-recognized set of service quality dimensions, as offered by (Anantharanthan Parasuraman et al. (1985); V. A. Z. Parasuraman et al. (1988)) such as "tangibility, reliability, responsiveness, communication, credibility, security, competence, courtesy, understanding/knowing the customer, and access" appear to be the most widely reported phenomenon. Later, a process factor analysis by A Parasuraman et al. (2002) compacted them into five factors "tangibles, reliability, responsiveness, assurance and empathy".

Henceforth, in the viewpoint of SERVQUAL, the five of the proposed dimensions of service quality must complement in any services or products offered in the market. These SERVQUAL dimensions facilitate the firms accurately gauge the customer's perception about the firm, the level of satisfaction and loyalty of customers (Ahmed, 2016; V. A. Z. Parasuraman et al., 1988). Also, the perception regarding the service quality and its influence on the behavior of customers have been a serious agenda distressing the organizational performance and the sustainability of the organization (Carrillat, Jaramillo, \& Mulki, 2007; Y. Kim, Kim, \& Lee, 2011). Considering this fact, the present study focusing on the perception of Fast Moving Consumers Goods customer on service quality dimensions through psychometric properties of SERVQUAL construct in relation to customer loyalty.

Following are the explanation of SERVQUAL dimensions which include:

Sukkur IBA Journal of Management and Business - SIJMB | Volume 4 No. 2 July - December 2017 @) Sukkur IBA University 


\subsubsection{Tangibles}

Anantharanthan Parasuraman et al. (1985) Defined tangibility as the physical appearance of announced facilities, materials, equipment's, and the service personnel. The physical characteristics of products or services or retail outlets or firm operated outlets attract customers directly while following their shopping activities. Also, the supporting factors including the business environment and the friendly interaction of the staff with the customers also considered by the customers (Raza, Siddiquei, Awan, \& Bukhari, 2012). Also, V. A. Z. Parasuraman et al. (1988) stated that the dimension of tangibles covers the physical setting of an organization, the different kind of services provided and the materials or equipment used for communication. Conversely, the physical characteristics and staff presentation often can increase the incongruity between customer's expectation and perception Urban (2010), even though it is significant that the supportive and convenient environment provided to the customers developed the favorable service quality perception (Nguyen, 2012).

\subsubsection{Reliability}

Reliability is deemed as the conformance of the firm's all promised services. According to V. A. Z. Parasuraman et al. (1988) reliability is the essential dimension of the overall service quality which deals with the fulfillment of the undertaken promises by the firm to provide the quality-orientated services in a perfect as well as reliable manner. The conception of reliability in the retail market refers to the accuracy and timeliness of the sales and service staff while dealing with the customer's complaints and promises made with the customers ( $\mathrm{He} \& \mathrm{Li}, 2011)$. Consequently, it can greatly affect the perception of the customers regarding the service quality. Past studies recommended the reliability as one of the significant feature which form the perception of the customers on service quality (Dabholkar, 1996).

\subsubsection{Responsiveness}

The term responsiveness refers to the promptness of the firm to accommodate their customers quickly. According to Anantharanthan Parasuraman et al. (1985) responsiveness is defined as the enthusiasm of the firm staff to provide the timely and quality services. Also, responsiveness involves understanding of the customers' needs and wants, attention given by staff to individual customer, suitable dealing hours, and responsible attitude of staff towards customer's problems and financial transactions (M. Kumar, Tat Kee, \& Taap Manshor, 2009). As a consequence, the way staff deals with the customers, directly affects the perception of the customers regarding service quality. Urban (2010) indicated that the enthusiasm and willingness of the service staff in dealing the customers is align with the responsiveness and helpfulness attitude of the firm as highlighted by the (V. A. Z. Parasuraman et al., 1988). Therefore, the responsiveness attitude of the staff wins the customers confidence which in turn directly enhance the perception of the customers towards firm's service quality (Haque, Sarwar, Yasmin, \& Anwar, 2012).

Sukkur IBA Journal of Management and Business - SIJMB | Volume 4 No. 2 July - December 2017 @ Sukkur IBA University 


\subsubsection{Assurance}

The notion of the assurance refers to the trustworthiness, understanding and courteousness of the employees. According to Anantharanthan Parasuraman et al. (1985) defined assurance as the courtesy and knowledge of the staff and their ability to develop trust and confidence among their customers. Also, the perception of the service quality is mainly depend on the staff ability in imparting the confidence among their customers. Furthermore, it is associated with the staff appropriateness in understanding the customer's desires and the considerable knowledge they must have to answer the customer's questions (S. A. Kumar, Mani, Mahalingam, \& Vanjikovan, 2010). To align with the customers' expectations, the staff need to allocate proper time to deal with their customer in order to increase his/her confidence (Haque et al., 2012). Conversely, in case of failure, in doing so may lead to a negative impression on customer confidence (Liu, Guo, \& Hsieh, 2010).

\subsubsection{Empathy}

The notion of the empathy refers to the capability of the firm to provide individual attention to their customers. According to the Anantharanthan Parasuraman et al. (1985) defined empathy as the kindness and attention given by the firm to its customers. Empathy involves the staff capability in understanding the customer's needs, giving them individual attention and facilitate with the suitable business hours.

\subsection{Service Quality Measurement}

Since, the formulation of SERVQUAL by V. A. Z. Parasuraman et al. (1988) accompanied by its latest refinements in (1991), had been tested in a diverse service industry in various countries. Its psychometric dependability has been questioned by a number of authors due to its reliance on a dual scale (measuring perceptions and expectations) rather than a single, simple, shorter and more effective scale (that of perception only). However, it persists to be one of the most extensively acknowledged tools for evaluating service quality.

\subsection{Relationship between Service Quality and Customer Loyalty}

In the pertinent literature, the notion of service quality has been considered as the antecedent of customer loyalty (Wieringa \& Verhoef, 2007). Past studies have attempted to explain the relationship between customer loyalty and its determinants, hence found the service quality as the strong determining factor which leads to competitive advantage and organizational success (Guo, Xiao, \& Tang, 2009). The provision of good service quality works as the kind action of the service provider (firms), which in turn reciprocates the loyalty of the customer and vice versa (Falk \& Fischbacher, 2006; Lai, Griffin, \& Babin, 2009). Among the prominent scholars, service quality has been regarded as a strong predictor of customer loyalty (Ganguli \& Roy, 2011). 
Furthermore, previous studies have described that customer loyalty has been created through two ways, impressing the customers R. L. Oliver (1999) and providing them greater quality products or services (H. H. Chang, Wang, \& Yang, 2009). It is also strongly recommended by the scholars that the service quality should be enhanced in order to influence the loyalty among customers (Al-Refai, 2015). In contrast, poor delivery of service quality adversely affects the service provider and customer relationship and loses in the shape of compensation to the customers (Wang, 2010).

Besides, numerous previous studies have investigated the service quality and customer loyalty relationship in different settings (Al-Refai, 2015). For instance, Ishaq (2012) has examined the relationship between service quality and customer loyalty among the Pakistan mobile phone users. The study found the significant positive service quality and customer loyalty relationship. Y.-E. Kim and Lee (2010) recommended the service quality as a strong predictor of customer loyalty. In addition to that, the relationship between each dimension of service quality and customer loyalty has been rarely examined. Al-Rousan and Mohamed (2010) examined the relationship between each dimension of the service quality and customer loyalty. The study was conducted in the context of Jordanian hotels. Their study revealed the significant positive results regarding each dimension and customer loyalty. Similarly, the study of M. Ali and Raza (2017) also examined the effect of each dimension of service quality on the customer satisfaction from the perspective of Islamic banks customers in Pakistan. The study also found the significant positive outcomes explaining the existence of a relationship of each dimension with the customer satisfaction. Hence, it is recommended to study further the impression of each dimension of service quality in order to validate the SERVQUAL model in the Pakistan context.

\subsection{Hypotheses Development}

The above review of the literature encourages the researchers to study further the service quality and its relationship with the customer loyalty and the relationship of each dimension of service quality with the customer loyalty from the FMCG customers' perspective, especially in the Pakistan market. Based on the past empirical findings, the following hypotheses have been formulated:

H1: There will be a positive relationship between service quality and customer loyalty.

H2: There will be a positive relationship between tangibility dimension of service quality and customer loyalty.

H3: There will be a positive relationship between reliability dimension of service quality and customer loyalty.

H4: There will be a positive relationship between responsiveness dimension of service quality and customer loyalty.

Sukkur IBA Journal of Management and Business - SIJMB | Volume 4 No. 2 July - December 2017 @) Sukkur IBA University 
H5: There will be a positive relationship between assurance dimension of service quality and customer loyalty.

H6: There will be a positive relationship between empathy dimension of service quality and customer loyalty.

\section{Methodology}

\subsection{Sample Selection and Sampling Technique}

Desired data were collected from the customers of FMCG firms operating in Southern Punjab. For this study, the stratified sampling technique was used to determine the sample. The sample was taken into two strata on the basis of homogeneous characteristics of FMCG firms that are National and Multinational FMCG firms. The present study adopted 21-items of SERVQUAL scale and for conducting validation, the Bentler and Chou (1987) assumption of 15 participants for each parameter being assessed (Schreiber, Nora, Stage, Barlow, \& King, 2006). To make more authentic validation of the scale, the sample size was doubled. Therefore, the sample size of 600 was taken into account for the present study and the questionnaires were sent to the customers of selected FMCG firms, out of which 476 questionnaires were collected and only 400 were usable, representing the response rate of $66.67 \%$.

\subsection{Instrument}

A 21-items scale of SERVQUAL recommended by A Parasuraman et al. (2002) was adapted in this study with its five dimensions, namely "Tangibility, Responsiveness, Reliability, Assurance, and Empathy" with their respective 4-items, 4-items, 5-items, 3 -items and 5-items of each dimension. And to measure the customer loyalty an 8-items scale recommended by Chaudhuri and Holbrook (2001) was adapted in the current study. A 5-point Likert scale was used to facilitate respondents to react conveniently, where 1 has been coded as "Strongly Disagree" and the 5 as "Strongly Agree".

\subsection{Demographic Profile}

Out of 400 usable respondents, $63.8 \%$ appear to be male and $36.2 \%$ were females. Concerning the age group of respondents, the highest group (64\%) was composed of 21 to 30 years of age and the age group of 60 or above represented the lowest group $(0.2 \%)$. With respect to the marital status, $37 \%$ customers are married and $63 \%$ are single. Moreover, in terms of qualification, the respondents with Masters' qualification, turn out to represent majority that is $(52.5 \%)$ while the ones with a bachelor's degree were (35.5\%). Respondents with the doctoral qualification were only $1.2 \%$ that is 5 out of 400 and $43(10.8 \%)$ have the qualification of MPhil. More importantly, with respect to the given strata, $30 \%$ customers are using products of National FMCG firms and 70\% are using products of Multinational FMCG firms.

\section{Analysis and Results}

To assess the effectiveness of SERVQUAL scale in the FMCG industry of Pakistan, the present study adopted the use of PLS path modelling to analyze the data by using 
Smart-PLS 3.0 (Ringle, Wende, \& Becker, 2015). This structural equation modelling technique is gaining popularity around the globe due to its user friendly approach and other powerful mechanics. Beside its numerous other powerful functions, this approach is highly recommended as a useful tool when the objective of the study is to test and validate the models (Hair, Sarstedt, Ringle, \& Mena, 2012; Henseler, Ringle, \& Sinkovics, 2009). Referring on the suggestions put forward by Wold (1975), the present study adopted Smart-PLS 3.0 for the data analysis. Looking into the nature of the analysis and purpose of the present study, the validation of the SERVQUAL scale and customer loyalty scale has been assessed using measurement model approach and thereafter the hypotheses were assessed using the structural model. In doing so, PLS Algorithm was calculated to ascertain the individual item-reliability, internalconsistency reliability, convergent validity and discriminant validity of the measures (Geladi \& Kowalski, 1986; Henseler et al., 2009). Consequently, bootstrapping was examined and then results are subsequently presented and discussed in the following sub-sections.

\subsection{Measurement Model Evaluation}

Looking at the nature of the study, it is significant to determine the reliability of each item in the SERVQUAL scale and customer loyalty scale. The present study assessed the individual item reliability by observing the outer loadings (Duarte \& Raposo, 2010; J. F. Hair Jr, Hult, Ringle, \& Sarstedt, 2016). Researchers have mutually agreed over 0.40 and 0.70 as a rule of thumb to determine individual item reliability (J. F. Hair Jr et al., 2016). Following Table 1 shows the outer loadings of the SERVQUAL scale adopted in the present study.

Table 1: Measurement Model

\begin{tabular}{llllc}
\hline Construct & Item & $\begin{array}{l}\text { Outer } \\
\text { Loadings }\end{array}$ & $\begin{array}{l}\text { Composite } \\
\text { Reliability (CR) }\end{array}$ & $\begin{array}{l}\text { Average Variance } \\
\text { Extracted (AVE) }\end{array}$ \\
\hline Assurance & ASSR1 & 0.773 & 0.786 & 0.647 \\
& ASSR2 & 0.835 & & \\
Empathy & EMP2 & 0.783 & 0.796 & 0.565 \\
& EMP3 & 0.742 & & \\
Reliability & EMP4 & 0.729 & & 0.575 \\
& REL2 & 0.746 & 0.802 & \\
& REL3 & 0.733 & & 0.526 \\
Responsiveness & REL4 & 0.795 & & \\
& RESP2 & 0.718 & 0.769 & 0.532 \\
\multirow{5}{*}{ Tangibility } & RESP3 & 0.756 & & \\
& RESP4 & 0.700 & & 0.506 \\
& TAN1 & 0.706 & 0.773 & \\
Customer Loyalty & TAN2 & 0.760 & & \\
& TAN4 & 0.721 & & \\
& CL4 & 0.639 & 0.803 & \\
& CL5 & 0.674 & & \\
& CL7 & 0.782 & & \\
\hline
\end{tabular}




CL8 0.741

Note: ASSR3, EMP1, EMP5, REL1, REL5, RESP1, TAN3, CL1, CL2, CL3, CL6 were deleted due to lower loadings.

The outer loadings for the 15-items of the SERVQUAL scale were found greater than the standard cutoff value of 0.4 (J. F. Hair Jr et al., 2016). Finally, from SERVQUAL scale, 14-items were retained for a total of 21-items; 7-items in this construct were deleted due to lower loadings. From customer loyalty construct, out of total 8-items, 4items were deleted and rest 4-items with greater loadings were retained. The overall retained outer loadings ranged from 0.639 to 0.835 . This ensured that all the taken items have sufficiently met the criteria of individual item reliability.

The internal-consistency reliability denotes "the degree to which every item on an individual scale (or sub scale) measures the same concept" (Bijttebier et al., 2000). Cronbach's alpha coefficient and composite reliability appeared to be the widely-used methods to estimate internal-consistency reliability in the past (refers (McCrae, Kurtz, Yamagata, \& Terracciano, 2011; Peterson \& Kim, 2013)). Present study employed composite reliability coefficient for determining internal-consistency reliability of the SERVQUAL scale and customer loyalty scale (Bagozzi \& Yi, 1988; Hair, Ringle, \& Sarstedt, 2011). According to the Hair et al. (2011), a construct meets composite reliability criterion when it scores 0.7 or more. The composite reliability coefficients provided in Table 1, shows that all the constructs of the present study have ranged from 0.769 to 0.803 . These coefficient scores suggest that the scale of the present study has demonstrated adequate amount of internal-consistency reliability (Hair et al., 2011).

The convergent validity demonstrates "the degree to which items truly represent the intended latent constructs and correlate with other measures of the same latent construct" (J. Hair Jr, Black, Babin, Anderson, \& Tatham, 2006). The convergent validity was ascertained on the basis of Average Variance Extracted (AVE) of the latent constructs. This was followed on the guidelines of Chin (1998), according to whom, the AVE loadings should be 0.5 or above for each of the latent construct. Table 1 outlines that the average variance extracted for the SERVQUAL scale and customer loyalty is equal or greater than 0.5 respectively. This further suggests that the current study has successfully demonstrated the convergent validity.

Last, the current study attempted to assess discriminant validity of all the latent variables. The discriminant validity denotes the degree to which a given latent variable is different from other latent variables (Duarte \& Raposo, 2010). The discriminant validity is assessed upon the guidelines of Fornell and Larcker (1981), according to whom, the square root of the average variance extracted should be above than the correlations among latent variables. The square-root of AVE (in the boldface values) and correlations among latent constructs are provided in Table 2.

Sukkur IBA Journal of Management and Business - SIJMB | Volume 4 No. 2 July - December 2017 @) Sukkur IBA University 
Table 2: Construct's Discriminant Validity

\begin{tabular}{lllllll}
\hline & ASSR & CL & EMP & REL & RESP & TAN \\
\hline ASSR & $\mathbf{0 . 8 0 4}$ & & & & & \\
CL & 0.374 & $\mathbf{0 . 7 1 1}$ & & & & \\
EMP & 0.293 & 0.507 & $\mathbf{0 . 7 5 2}$ & & & \\
REL & 0.342 & 0.368 & 0.330 & $\mathbf{0 . 7 5 8}$ & & \\
RESP & 0.357 & 0.473 & 0.464 & 0.430 & $\mathbf{0 . 7 2 5}$ & \\
TAN & 0.333 & 0.457 & 0.417 & 0.341 & 0.450 & $\mathbf{0 . 7 2 9}$ \\
\hline
\end{tabular}

The boldface values provided in table 2 are the square root of the average variance extracted. The AVE values suggest that all the latent constructs have successfully demonstrated a sufficient level of discriminant validity; as all the values of the square root of AVE were greater than the correlations. It is, therefore, concluded that all the measures of the SERVQUAL scale and customer loyalty scale have met the discriminant validity requirements. Figure 1 shows the measurement model of the study.

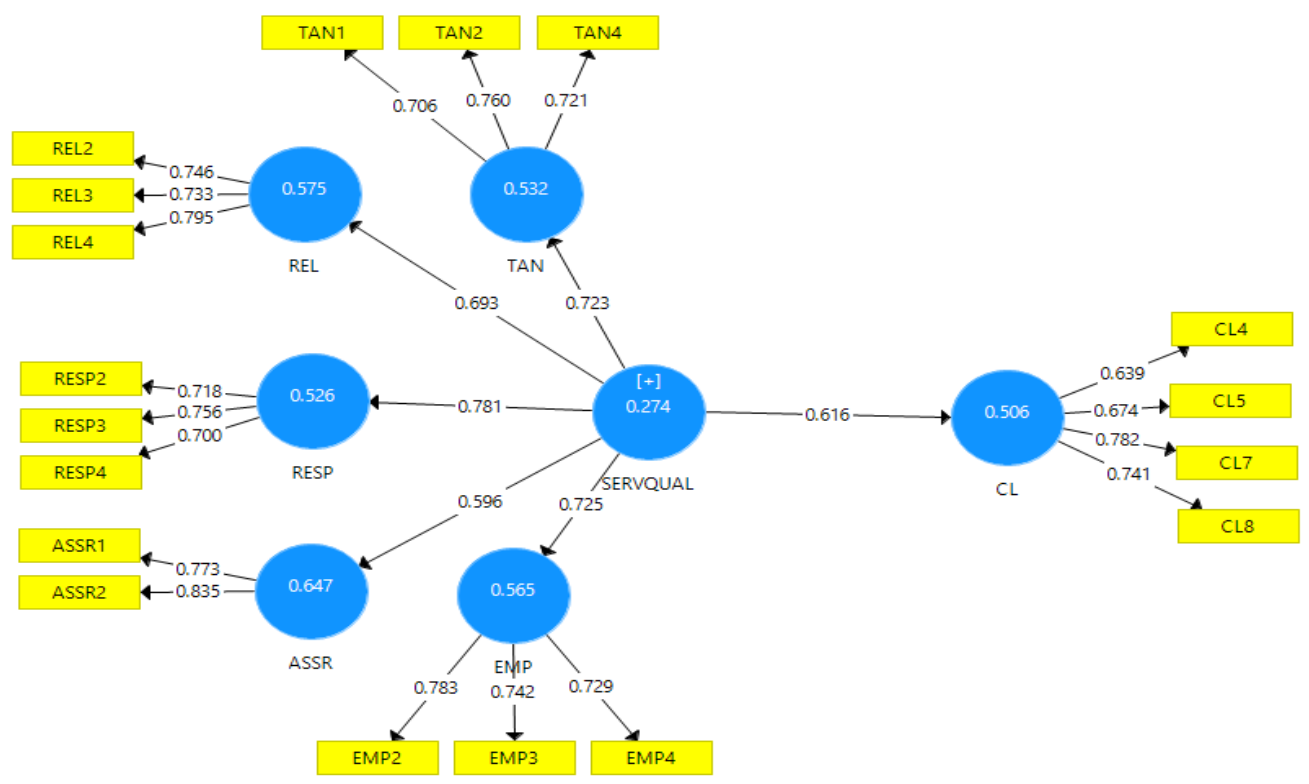

Figure 1: Measurement Model

\subsection{Structural Model Evaluation}

After the measure model evaluation, structural model was assessed to test the six hypotheses formulated in this study. Table 3 provides the findings of the path analysis. The findings revealed that all the tested hypotheses where SERVQUAL $(\beta=0.616$, $\mathrm{t}=17.143, \mathrm{p}<0.00)$, TAN $(\beta=0.185, \mathrm{t}=3.586, \mathrm{p}<0.00)$, REL $(\beta=0.098, \mathrm{t}=2.145, \mathrm{p}<0.00)$, $\operatorname{RESP}(\beta=0.168, \mathrm{t}=3.184, \mathrm{p}<0.00)$, ASSR $(\beta=0.135, \mathrm{t}=2.898, \mathrm{p}<0.00)$, and EMP 
$(\beta=0.284, \mathrm{t}=5.590, \mathrm{p}<0.00)$ significantly related to the customer loyalty and all the variables explaining the $37.9 \%$ variance in the customer loyalty. Hence, hypothesis $\mathrm{H} 1$, $\mathrm{H} 2, \mathrm{H} 3, \mathrm{H} 4, \mathrm{H} 5$, and $\mathrm{H} 6$ were accepted and shown in figure 2 and figure 3.

Table 3: Hypotheses Testing

\begin{tabular}{lllllll}
\hline Hypotheses & Relationships & Beta & SE & $\begin{array}{l}\text { T- } \\
\text { Value }\end{array}$ & $\begin{array}{l}\text { P- } \\
\text { Value }\end{array}$ & Decision \\
\hline H1 & SERVQUAL -> & 0.616 & 0.036 & 17.143 & 0.000 & Supported \\
& CL & & & & & \\
H2 & TAN -> CL & 0.185 & 0.052 & 3.586 & 0.000 & Supported \\
H3 & REL -> CL & 0.098 & 0.046 & 2.145 & 0.016 & Supported \\
H4 & RESP -> CL & 0.168 & 0.053 & 3.184 & 0.001 & Supported \\
H5 & ASSR -> CL & 0.135 & 0.047 & 2.898 & 0.002 & Supported \\
H6 & EMP -> CL & 0.284 & 0.051 & 5.590 & 0.000 & Supported \\
\hline
\end{tabular}

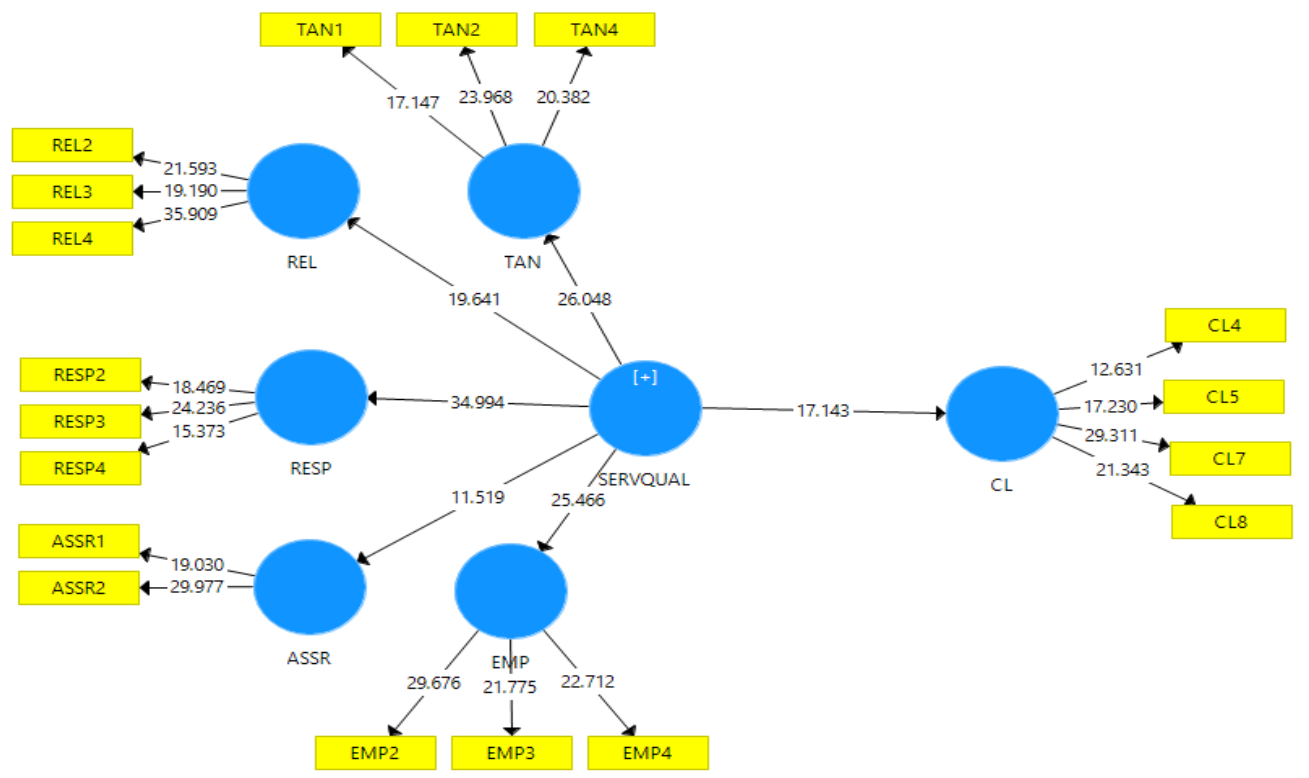

Figure 2: Structural Model SERVQUAL to CL 


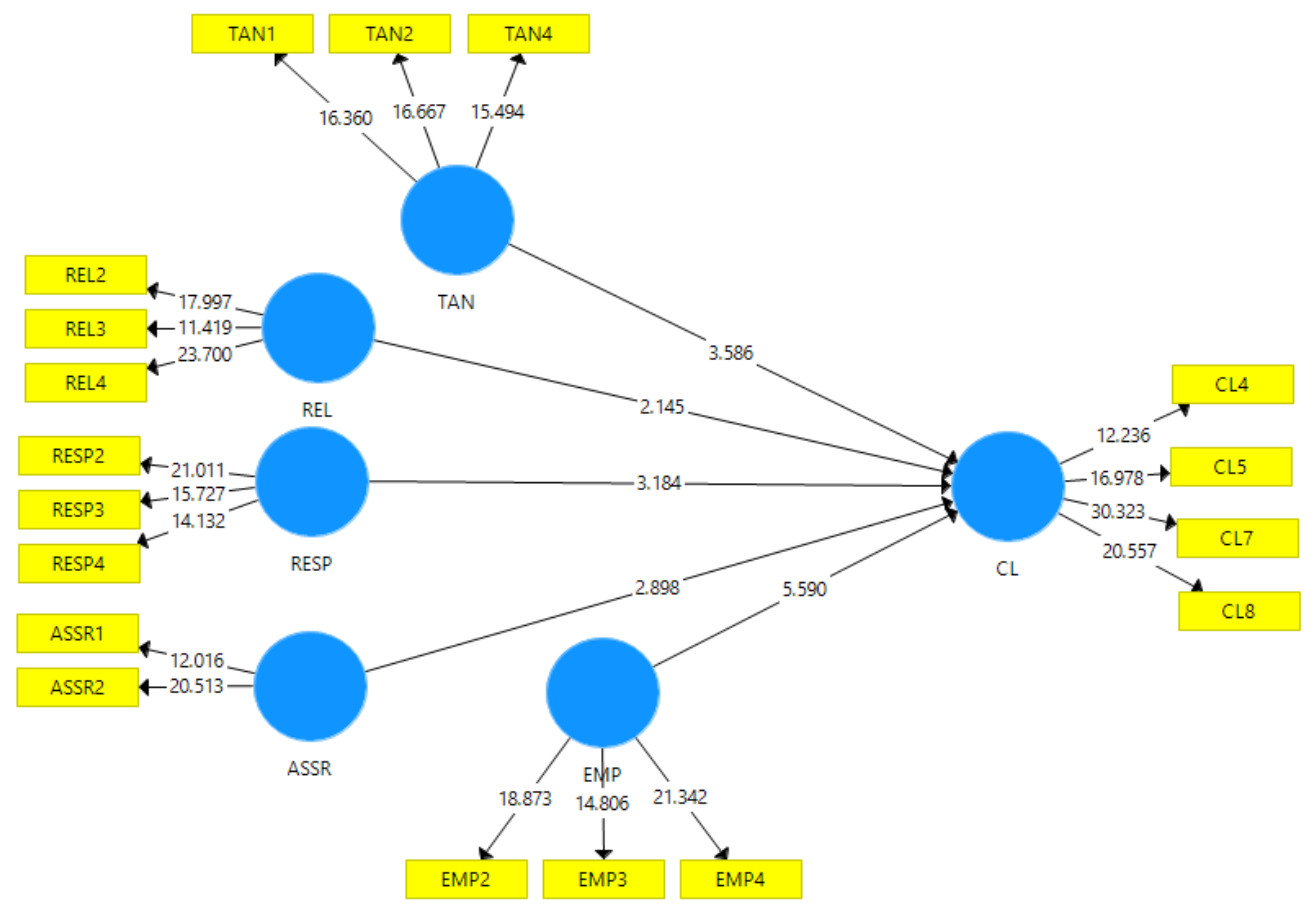

Figure 3: Structural Model SERVQUAL Dimensions to CL

As per the recommendation of J. F. Hair Jr et al. (2016), predictive relevance $\left(\mathrm{Q}^{2}\right)$ was also calculated through blindfolding procedure using a distance interval of 7 in SmartPLS 3.0. The purpose to calculate the $\mathrm{Q}^{2}$ value is to estimate the model parameters and to predict the omitted part using these parameters (Hair et al., 2013). As the $Q^{2}$ value of this model is 0.180 with only single endogenous variable that is customer loyalty and greater than 0 , hence depicts that the model is accepted and having satisfactory predictive power (Fornell \& Larcker, 1981).

\section{Discussion}

The current study makes an effort to empirically validate the Service Quality (SERVQUAL) scale developed by A Parasuraman et al. (2002) in relation to the customer loyalty in the Pakistan FMCG market context, especially looking into the customers of Multinational and National FMCGs firms operating in South Punjab, Pakistan. The construct of SERVQUAL has met the criteria and recommend that this tool is appropriate in measuring service quality in the FMCG market of Pakistan. Additionally, the SERVQUAL scale was developed and tested in the developed country context. Therefore, it is important to look into the question that how do SERVQUAL scale scores in the developing countries especially with regards to Pakistan. The outcomes of the measurement model and structural model regarding the reliability and validity tests inform that the SERVQUAL is appropriate in measuring any or all of the 
service quality parameters consisting of tangibility, reliability, responsiveness, assurance and empathy.

Also, the current study initially measured the direct effect of service quality on customer loyalty and found significant and positive results. Thereafter, the relationship between each dimension of service quality and customer loyalty were examined and found the significant positive results. These findings of the current study highlighted that the perception of the customers regarding overall service quality influences their loyalty with the organization and its products. Likewise, Pakistani consumers also become loyal with the provision of tangibility, reliability, responsiveness, assurance, and empathy. Moreover, the sales and service staff of the FMCG firms played very vital role in the development of the good perception of service quality which increases the positive word of mouth and ultimately influences the customer loyalty.

In general, the findings of the current study are consistent with the past studies that focus on the customers perceived service quality and its impact on their customer's loyalty. For instance, the study of Al-Refai (2015) also examined the relationship between service quality and customer loyalty among the mobile phone users. The study analyzed the overall impact of service quality on the customer loyalty and revealed the significant relationship between service quality and customer loyalty. Similarly, the study of Ishaq (2012) investigated the relationship between service quality and customer loyalty among the Pakistan customers. By using the SERVQUAL model, his study also revealed the significant relationship between service quality and customer loyalty. In gist, there are also other studies which found the positive relationship between service quality and customer loyalty in different work settings (Bedi, 2010; Naeem, Akram, \& Saif, 2009). On the contrary, there are few studies on the SERVQUAL model conducted in developing countries like Iran and Bangladesh revealed negative results which showed the unsatisfactory perception of the customers regarding the service quality (Enayati, Modanloo, Behnamfar, \& Rezaei, 2013; Zabed Ahmed \& Hossain Shoeb, 2009). Furthermore, the findings suggest that the developing countries customers reveal repurchase intention and his/her loyalty with the firm product or service when they are satisfied with the service quality from all aspects. Hence, the findings of this study add value to the existing literature regarding the positive relationship between service quality and customer loyalty in the developing country i.e. Pakistan context.

Furthermore, in this study, the significant and positive results regarding the relationship between each dimension of the service quality and customer loyalty are also consistent with the findings of the past studies those examined the impact of each dimension of service quality on the customer loyalty (Al-Rousan \& Mohamed, 2010; M. Ali \& Raza, 2017). Accordingly, the current study findings confirm that each dimension of the service quality also contributes towards the development of the service quality. The customers are attracted by each aspect of the service quality. Therefore, the firms should 
focus on each aspect of the service quality in the delivery of the quality services to the customers, especially the Pakistan national FMCG firms should upgrade their quality standards and focus on the delivery of quality services to the customers in order to attain the competitive advantage and compete the with the multinational FMCG firms.

\section{Conclusion, Managerial Implications and Limitations}

The current study measures the SERVQUAL dimensions in the Pakistan context specifically on the perception of the customers of the FMCG firms. The study concluded that the better service quality is provided to the customers and firms focus on all aspects of the service quality lead towards the customer loyalty. Consequently, due to the less focus on the service quality, there is an increased in the dissatisfaction level of the customers and spread negative word of mouth which leads to customer changing attitude. Moreover, it will damage the image of the firm. In short, the validation of the SERVQUAL construct also contribute to the existing literature on the service quality construct especially in the developing countries context like Pakistan.

The study also develops the significant base for the other researchers and academicians of the developing countries to explore more deeply the SERVQUAL dimensionality. Also, the findings of the current study are very useful for the managers' sales and services, policy makers, marketing firm and for $\mathrm{R} \& \mathrm{D}$ oriented firms. The study guides the concern authorities in setting their objectives, strategic planning and more importantly with respect to cost minimization and profit maximization. The managers must focus on those service quality dimensions that directly impact psychologically on the perception level of the customers and increase their satisfaction level which in turn become their loyalty. Furthermore, it is necessary for the Fast Moving Consumer Goods Producing firms to collect information about the attitude and behavior of their customers in order to retain them and attract the new customers. Pakistan Fast Moving Consumer Goods market have now big competition because the both Multinationals and National firms focusing on the quality of the services and products which shows the huge importance of the service quality dimensionality and practicability in the Pakistan context. This is the reason, now a day's firms focus on the improvement of the service quality which influences their customers' satisfaction as well as loyalty (Kotler \& Keller, 2009). In this way, the current study adds more value in the literature through assessing the SERVQUAL dimensions in relation to customer loyalty.

Although due to the limitations related to time and cost, the sample for the present study was limited to the one province of the country. Therefore, it could be potentially tested with a larger sample in the same industry or an analysis is recommended using the multiple industry samples. Yet, it is highly advised to the future researchers and business consultants to evaluate service quality using the SERVQUAL scale in the Pakistan Retail market or FMCG sector. Furthermore, it is recommended to adopt qualitative approach by the researchers in order to determine the experiences of the frequent customers through interviews which will contribute more deeply into the

Sukkur IBA Journal of Management and Business - SIJMB | Volume 4 No. 2 July - December 2017 @ Sukkur IBA University 
understanding of the service quality and its dimensions. This is the basic exploratory study which assesses the validation of the SERVQUAL construct and based on the findings of this study the scale can also be used in the different context in Pakistan. To get the stronger perception on the service quality, it is recommended to study on the perception of the internal customers and make comparison with the external customer's perception on service quality. Also, due to the limitation of the current study, the internal customers who delivers the service quality to the external customers are not considered. Considering this limitation, it is recommended to study the relationship of the SERVQAUL construct with the employees and could analyzed their perception regarding the dimensions of the service quality which they delivered to the external customers.

\section{References}

Ahmed, A., \& Malik, M. S. (2016). Strategy to Customer Loyalty: Building CSR and Service Quality: LAP LAMBERT Academic Publishing Germany.

Akbar, M. M., \& Parvez, N. (2009). Impact of service quality, trust, and customer satisfaction on customers loyalty. ABAC Journal, 29(1).

Al-Refai, A. N. S. (2015). Factors influencing customers' loyalty of mobile service provider among generation $Y$. Universiti Utara Malaysia.

Al-Rousan, M. R., \& Mohamed, B. (2010). Customer loyalty and the impacts of service quality: The case of five star hotels in Jordan. International journal of human and social sciences, 5(13), 886-892.

Ali, F., Zhou, Y., Hussain, K., Nair, P. K., \& Ragavan, N. A. (2016). Does higher education service quality effect student satisfaction, image and loyalty? A study of international students in Malaysian public universities. Quality Assurance in Education, 24(1), 70-94.

Ali, M., \& Raza, S. A. (2017). Service quality perception and customer satisfaction in Islamic banks of Pakistan: the modified SERVQUAL model. Total Quality Management \& Business Excellence, 28(5-6), 559-577.

Ammar Ahmed, P. M. D. I. L. O. (2016). Mediating Role of Customer Commitment on Customer Loyalty in FMCG. Scholars Journal of Economics, Business and Management, 3(5), 263-270.

Asubonteng, P., McCleary, K. J., \& Swan, J. E. (1996). SERVQUAL revisited: a critical review of service quality. Journal of services marketing, 10(6), 62-81.

Bagozzi, R. P., \& Yi, Y. (1988). On the evaluation of structural equation models. Journal of the Academy of Marketing Science, 16(1), 74-94.

Balaji, M. S. (2009). Customer satisfaction with Indian mobile services. IUP Journal of Management Research, 8(10), 52.

Bedi, M. (2010). An integrated framework for service quality, customer satisfaction and behavioral responses in Indian banking industry-a comparison of public and private sector banks. Journal of Services Research, 10(1), 157.

Bentler, P. M., \& Chou, C.-P. (1987). Practical issues in structural modeling. Sociological Methods \& Research, 16(1), 78-117. 
Bijttebier, P., Delva, D., Vanoost, S., Bobbaers, H., Lauwers, P., \& Vertommen, H. (2000). Reliability and validity of the Critical Care Family Needs Inventory in a Dutch-speaking Belgian sample. Heart \& Lung: The Journal of Acute and Critical Care, 29(4), 278-286.

Buell, R. W., Campbell, D., \& Frei, F. X. (2016). How do customers respond to increased service quality competition? Manufacturing \& Service Operations Management, 18(4), 585-607.

Carrillat, F. A., Jaramillo, F., \& Mulki, J. P. (2007). The validity of the SERVQUAL and SERVPERF scales: A meta-analytic view of 17 years of research across five continents. International Journal of Service Industry Management, 18(5), $472-490$.

Chang, H. H., Wang, Y.-H., \& Yang, W.-Y. (2009). The impact of e-service quality, customer satisfaction and loyalty on e-marketing: Moderating effect of perceived value. Total Quality Management, 20(4), 423-443.

Chang, M. J., Kang, J.-H., Ko, Y. J., \& Connaughton, D. P. (2017). The effects of perceived team performance and social responsibility on pride and word-ofmouth recommendation. Sport Marketing Quarterly, 26(1), 31.

Chaudhuri, A., \& Holbrook, M. B. (2001). The chain of effects from brand trust and brand affect to brand performance: the role of brand loyalty. Journal of Marketing, 65(2), 81-93.

Chin, W. W. (1998). The partial least squares approach to structural equation modeling. Modern methods for business research, 295(2), 295-336.

Chou, P.-F., Lu, C.-S., \& Chang, Y.-H. (2014). Effects of service quality and customer satisfaction on customer loyalty in high-speed rail services in Taiwan. Transportmetrica A: Transport Science, 10(10), 917-945.

Chumpitaz, R., \& Paparoidamis, N. G. (2004). Service quality and marketing performance in business-to-business markets: exploring the mediating role of client satisfaction. Managing Service Quality: An International Journal, 14(2/3), 235-248.

Dabholkar, P. A. (1996). Consumer evaluations of new technology-based self-service options: an investigation of alternative models of service quality. International Journal of research in Marketing, 13(1), 29-51.

Dowling, G. R., \& Uncles, M. (1997). Do customer loyalty programs really work? Sloan management review, 38(4), 71.

Duarte, P. A. O., \& Raposo, M. L. B. (2010). A PLS model to study brand preference: An application to the mobile phone market Handbook of partial least squares (pp. 449-485): Springer.

Economist, T. (2013, January 19, 2018). Consumer goods. from http://www.eiu.com/industry/article/141041398/pakistan-fmcgs-provide-aneconomic-bright-spot/2013-10-09

Enayati, T., Modanloo, Y., Behnamfar, R., \& Rezaei, A. (2013). Measuring service quality of Islamic Azad University of Mazandaran using SERVQUAL model. Iranian journal of management studies, 6(1), 101. 
Falk, A., \& Fischbacher, U. (2006). A theory of reciprocity. Games and economic behavior, 54(2), 293-315.

Fornell, C., \& Larcker, D. F. (1981). Evaluating structural equation models with unobservable variables and measurement error. Journal of marketing research, 39-50.

Ganguli, S., \& Roy, S. K. (2011). Generic technology-based service quality dimensions in banking: Impact on customer satisfaction and loyalty. International journal of bank marketing, 29(2), 168-189.

Geladi, P., \& Kowalski, B. R. (1986). Partial least-squares regression: a tutorial. Analytica chimica acta, 185, 1-17.

Gounaris, S. P., Tzempelikos, N. A., \& Chatzipanagiotou, K. (2007). The relationships of customer-perceived value, satisfaction, loyalty and behavioral intentions. Journal of Relationship Marketing, 6(1), 63-87.

Guo, L., Xiao, J. J., \& Tang, C. (2009). Understanding the psychological process underlying customer satisfaction and retention in a relational service. Journal of business research, 62(11), 1152-1159.

Gupta, A. K., Si, S., \& Si, S. (2016). Service Marketing: Customer Expectations and Delight With Reference To Indian Banking Sector. Imperial Journal of Interdisciplinary Research, 2(4).

Gurău, C. (2003). Tailoring e-service quality through CRM. Managing Service Quality: An International Journal, 13(6), 520-531.

Hair, J. F., Ringle, C. M., \& Sarstedt, M. (2011). PLS-SEM: Indeed a silver bullet. Journal of Marketing theory and Practice, 19(2), 139-152.

Hair, J. F., Sarstedt, M., Ringle, C. M., \& Mena, J. A. (2012). An assessment of the use of partial least squares structural equation modeling in marketing research. Journal of the Academy of Marketing Science, 40(3), 414-433.

Hair Jr, J., Black, W., Babin, B., Anderson, R., \& Tatham, R. (2006). Multivariate Data Analysis . Upper Saddle River, NJ: Prentice-Hall International.

Hair Jr, J. F., Hult, G. T. M., Ringle, C., \& Sarstedt, M. (2016). A primer on partial least squares structural equation modeling (PLS-SEM): Sage Publications.

Haque, A., Sarwar, A. A. M., Yasmin, F., \& Anwar, A. (2012). The impact of customer perceived service quality on customer satisfaction for private health centre in Malaysia: a structural equation modeling approach. Information Management and Business Review, 4(5), 257.

Hartline, M. D., \& Jones, K. C. (1996). Employee performance cues in a hotel service environment: Influence on perceived service quality, value, and word-of-mouth intentions. Journal of business research, 35(3), 207-215.

He, H., \& Li, Y. (2011). CSR and service brand: The mediating effect of brand identification and moderating effect of service quality. Journal of Business Ethics, 100(4), 673-688.

Henseler, J., Ringle, C. M., \& Sinkovics, R. R. (2009). The use of partial least squares path modeling in international marketing New challenges to international marketing (pp. 277-319): Emerald Group Publishing Limited. 
Hurley, R. F., \& Estelami, H. (1998). Alternative indexes for monitoring customer perceptions of service quality: A comparative evaluation in a retail context. Journal of the Academy of Marketing Science, 26(3), 209.

Ishaq, I. M. (2012). Perceived value, service quality, corporate image and customer loyalty: Empirical assessment from Pakistan. Serbian Journal of Management, 7(1), 25-36.

Khare, A., Parveen, C., \& Rai, R. (2010). Retailer behavior as determinant of service quality in Indian retailing. Journal of Retail \& Leisure Property, 9(4), 303-317.

Kim, Y.-E., \& Lee, J.-W. (2010). Relationship between corporate image and customer loyalty in mobile communications service markets. African Journal of Business Management, 4(18), 4035.

Kim, Y., Kim, Y., \& Lee, Y. (2011). Perceived service quality for South Korean domestic airlines. Total Quality Management \& Business Excellence, 22(10), 1041-1056.

Kotler, P., \& Keller, K. L. (2009). Marketing management (13th end). New Jersey.

Kumar, M., Tat Kee, F., \& Taap Manshor, A. (2009). Determining the relative importance of critical factors in delivering service quality of banks: an application of dominance analysis in SERVQUAL model. Managing Service Quality: An International Journal, 19(2), 211-228.

Kumar, S. A., Mani, B. T., Mahalingam, S., \& Vanjikovan, M. (2010). Influence of service quality on attitudinal loyalty in private retail banking: an empirical study. IUP Journal of Management Research, 9(4), 21.

Lai, F., Griffin, M., \& Babin, B. J. (2009). How quality, value, image, and satisfaction create loyalty at a Chinese telecom. Journal of business research, 62(10), 980986.

Leahy, R. (2009). Brand loyalty in fast moving consumer good markets: the role of bonds. International Journal of Business and Management, 3(12), 7.

Lee, M. C., \& Hwan, S. (2005). Relationships among service quality, customer satisfaction and profitability in the Taiwanese banking industry. International journal of management, 22(4), 635.

Lewis, B. R. (1993). Service quality measurement. Marketing Intelligence \& Planning, 11(4), 4-12.

Liu, C.-T., Guo, Y. M., \& Hsieh, T.-Y. (2010). Measuring user perceived service quality of online auction sites. The Service Industries Journal, 30(7), 1177-1197.

McCrae, R. R., Kurtz, J. E., Yamagata, S., \& Terracciano, A. (2011). Internal consistency, retest reliability, and their implications for personality scale validity. Personality and social psychology review, 15(1), 28-50.

Moolla, A. I., \& Bisschoff, C. A. (2012). Validating a model to measure the brand loyalty of fast moving consumer goods. Journal of Social Sciences, 31(2), 101115.

Naeem, H., Akram, A., \& Saif, M. I. (2009). Service Quality and its impact on Customer Satisfaction: An empirical evidence from the Pakistani banking sector. The International Business \& Economics Research Journal, 8(12), 99. 
News, D. (2017). Here's what to expect from Pakistan's economy in 2017. Retrieved January 19, 2017, 2017, from https://www.dawn.com/news/1305569

Ngobo, P. V. (2017). The trajectory of customer loyalty: an empirical test of Dick and Basu's loyalty framework. Journal of the Academy of Marketing Science, 45(2), 229-250.

Nguyen, M. T. (2012). Effects of service quality and price fairness on student satisfaction. International Journal of Business and Social Science, 3(19).

Ofori, K. S., Boakye, K., \& Narteh, B. (2016). Factors influencing consumer loyalty towards 3G mobile data service providers: evidence from Ghana. Total Quality Management \& Business Excellence, 1-19.

Oliver, R. (1993). Advances in services marketing and management.

Oliver, R. L. (1999). Whence consumer loyalty? the Journal of Marketing, 33-44.

Parasuraman, A., Berry, L., \& Zeithaml, V. (2002). Refinement and reassessment of the SERVQUAL scale. Journal of retailing, 67(4), 114.

Parasuraman, A., Zeithaml, V. A., \& Berry, L. L. (1985). A conceptual model of service quality and its implications for future research. the Journal of Marketing, 4150 .

Parasuraman, V. A. Z., Berry, L. L., \& Zeithaml, V. A. (1988). A multiple item scale for measuring consumer perception on future research. Journal of Marketing, 49(1).

Peterson, R. A., \& Kim, Y. (2013). On the relationship between coefficient alpha and composite reliability. Journal of Applied Psychology, 98(1), 194.

Radojevic, T., Stanisic, N., \& Stanic, N. (2015). Ensuring positive feedback: Factors that influence customer satisfaction in the contemporary hospitality industry. Tourism Management, 51, 13-21.

Raza, M. A., Siddiquei, A. N., Awan, H. M., \& Bukhari, K. (2012). Relationship between service quality, perceived value, satisfaction and revisit intention in hotel industry. Interdisciplinary journal of contemporary research in business, 4(8), 788-805.

Ringle, C. M., Wende, S., \& Becker, J.-M. (2015). SmartPLS 3. Boenningstedt: SmartPLS GmbH.

Rootman, C. (2006). The influence of customer relationship management on the service quality of banks. Nelson Mandela Metropolitan University.

Sathiyabama, R., \& William, A. J. (2015). A STUDY ON RETAILERS SERVICE QUALITY IN SELECTED RETAIL OUTLETS IN COIMBATORE CITY.

Schreiber, J. B., Nora, A., Stage, F. K., Barlow, E. A., \& King, J. (2006). Reporting structural equation modeling and confirmatory factor analysis results: A review. The Journal of educational research, 99(6), 323-338.

Seth, N., Deshmukh, S., \& Vrat, P. (2005). Service quality models: a review. International journal of quality \& reliability management, 22(9), 913-949.

Singh, A. (2013). Relationship between service quality and customer satisfaction in organized retail outlets. Browser Download This Paper. 
Singh, A. (2016). Service Quality Models: A Gap Study. Business and Economic Research, 6(1), 464-480.

Sureshchandar, G., Rajendran, C., \& Anantharaman, R. (2002). The relationship between service quality and customer satisfaction-a factor specific approach. Journal of services marketing, 16(4), 363-379.

Survey, P. E. (2017). Overview of the Economy, Pakistan Economic Survery. Pakistan: Retrieved from http://www.finance.gov.pk/survey/chapters_17/overview_2016-17.pdf.

Tsoukatos, E., \& Rand, G. K. (2006). Path analysis of perceived service quality, satisfaction and loyalty in Greek insurance. Managing Service Quality: An International Journal, 16(5), 501-519.

Turel, O., \& Serenko, A. (2006). Satisfaction with mobile services in Canada: An empirical investigation. Telecommunications policy, 30(5-6), 314-331.

Urban, W. (2010). CUSTOMERS'EXPERIENCES AS A FACTOR AFFECTING PERCEIVED SERVICE QUALITY. Economics \& Management.

Wang, C. Y. (2010). Service quality, perceived value, corporate image, and customer loyalty in the context of varying levels of switching costs. Psychology \& Marketing, 27(3), 252-262.

Wieringa, J. E., \& Verhoef, P. C. (2007). Understanding customer switching behavior in a liberalizing service market: an exploratory study. Journal of Service Research, 10(2), 174-186.

Wilson, A., Zeithaml, V., Bitner, M. J., \& Gremler, D. (2016). Services marketing: Integrating customer focus across the firm: McGraw Hill.

Wold, H. (1975). Path models with latent variables: The NIPALS approach Quantitative sociology (pp. 307-357): Elsevier.

Yu, C.-m. J., Wu, L.-Y., Chiao, Y.-C., \& Tai, H.-S. (2005). Perceived quality, customer satisfaction, and customer loyalty: The case of Lexus in Taiwan. Total Quality Management \& Business Excellence, 16(6), 707-719.

Zabed Ahmed, S., \& Hossain Shoeb, Z. (2009). Measuring service quality of a public university library in Bangladesh using SERVQUAL. Performance Measurement and Metrics, 10(1), 17-32.

Zargar, M. (2016). An empirical assessment of the SERVQUAL scale. Accounting, $2(2), 85-88$. 